\title{
KUTU SISIK PADA CENDANA (Santalum album L.) DI KUPANG, NUSA TENGGARA TIMUR
}

\author{
Sandalwood scale insect in Kupang, Nusa Tenggara Timur \\ Eritrina Windyarini ${ }^{(1)}$ dan Illa Anggraeni ${ }^{(2)}$ \\ ${ }^{(1)}$ Balai Penelitian Kehutanan Kupang \\ Jl. Untung Suropati No. 7 Po. Box 67 Kupang - 85115, Telp. (0380) 823357, Fax. (0380) 831068 \\ ${ }^{(2)}$ Pusat Penelitian dan Pengembangan Peningkatan Produktivitas Hutan, Bogor \\ Jl. Gunung Batu No. 5 Bogor, Telp. (0251) 8631238, Fax. (0251) 7520005
}

Naskah masuk : 3 Januari 2010; Naskah diterima : 23 Desember 2010

\begin{abstract}
Cendana (Santalum album $L$ ) has high economical values due to its content of essential oil. In order to develop cendana plantation, it is required a high quality cendana seedlings. In the area of Cendana plantations at Nusa Tenggara Island, the trees have been attacked by Sandalwood Scale insect, which caused the death of cendana trees. This condition will inhibit development program of cendana. To prevent greater looses, we have to manage and control the pest efficiently and effectively. Prior to conducting the control action, sufficient knowledge about the pest is needed. The aim of this research was to identify the specific type of sandalwood scale insect and its suitable control technique. The result showed that the species of sandalwood scale insect was Chionaspis $s p$. (Homoptera: Diaspididae) which attacked the seedling and sapling in Kupang-East Nusa Tenggara. Treatment using insecticide with karbaril $85 \%$ content, could reduce the number of sandalwood scale insect population especially in the cendana seedling. Meanwhile, in the field of cendana plantation it could reduce the sandalwood scale insect attack by about 1,4\%, from 10,07\% before treatment to 8,67\% after treatment.
\end{abstract}

Keywords: Sandalwood, sandalwood scale insect, Chionaspis sp., carbaril 85\%

\begin{abstract}
ABSTRAK
Cendana (Santalum album L.) merupakan salah satu jenis pohon hutan yang mempunyai nilai ekonomi tinggi, karena menghasilkan minyak atsiri. Dalam pengembangan cendana tentunya diperlukan bibit yang sehat, tetapi kenyataan di lapangan bibit dan tanaman cendana di Pulau Timor (NTT) terserang hama kutu sisik yang mengakibatkan kematian. Hal ini tentunya dapat menghambat program pengembangan cendana. Pengendalian terhadap hama kutu sisik secara efektif dan efisien perlu dilakukan untuk mencegah kerugian yang lebih besar. Sebelum dilakukan pengendalian tentunya diperlukan pengetahuan yang memadai tentang hama tersebut. Tujuan penelitian ini adalah untuk mengetahui jenis hama kutu sisik dan upaya pengendaliannya. Hasil identifikasi menunjukkan bahwa kutu sisik yang menyerang bibit dan tanaman muda cendana di Kupang, Nusa Tenggara Timur adalah Chionaspis sp. (Homoptera: Diaspididae). Pengendalian dengan insektisida berbahan aktif karbaril $85 \%$ di tingkat semai dapat menurunkan jumlah populasi, sedangkan di tingkat lapangan dapat menurunkan persentase serangan sebesar $1,4 \%$, persentase serangan awal sebelum perlakuan $10,07 \%$ setelah perlakuan menjadi $8,67 \%$.
\end{abstract}

Kata kunci : Cendana, kutu sisik, Chionaspis sp., karbaril 85\% 


\section{PENDAHULUAN}

Cendana (Santalum album L.) merupakan salah satu jenis pohon hutan yang mempunyai nilai ekonomi tinggi, karena menghasilkan minyak atsiri dengan aroma yang harum. Kebutuhan minyak atsiri cendana dunia sekitar 200 ton per tahun, yang disuplai dari India 100 ton sedangkan Indonesia, Australia, Kaledonia Baru dan Fiji hanya mampu menyuplai 20 ton per tahun. Kekurangan 80 ton per tahun merupakan pangsa pasar yang menjanjikan (Anonim, 2010). Cendana yang ada di Nusa Tenggara Timur (NTT) mempunyai kandungan kadar minyak atsiri dan produksi kayu terasnya tinggi (Surata, 2006). Sementara populasi cendana di NTT sudah cukup memprihatinkan, oleh karena itu berbagai upaya dilakukan untuk mengembangkan cendana dengan melibatkan semua pihak baik pemerintah c.q Kementerian Kehutanan, swasta, maupun masyarakat. Dalam pengembangan cendana tentunya diperlukan bibit yang sehat, tetapi kenyataan di lapangan bibit dan tanaman cendana di Pulau Timor (NTT) terserang hama kutu sisik yang mengakibatkan kematian. Hal ini tentunya dapat menghambat program pengembangan cendana. Pengendalian terhadap hama kutu sisik secara efektif dan efisien perlu dilakukan untuk mencegah kerugian yang lebih besar. Sebelum dilakukan pengendalian tentunya diperlukan pengetahuan yang memadai tentang hama tersebut. Tujuan penelitian ini adalah untuk mengetahui jenis hama kutu sisik dan upaya pengendaliannya.

\section{BAHAN DAN METODE}

\section{A. Lokasi Penelitian}

Penelitian lapangan dilakukan di dua lokasi yaitu (1) di Persemaian Balai Penelitian Kehutanan (BPK) Kupang yang termasuk Kelurahan Airnona, Kecamatan Oedobo, Kabupaten Kupang, Provinsi Nusa Tenggara Timur. (2) di plot penanaman cendana di Desa Ponain, Kecamatan Amarasi, Kabupaten Kupang.

Kondisi biofisik di persemaian BPK Kupang, antara lain beriklim tropis, rata-rata penyinaran matahari $37-96 \%$, suhu udara ratarata musim hujan $26^{\circ} \mathrm{C}-27,8^{\circ} \mathrm{C}$, dan musim kemarau $25,3^{\circ} \mathrm{C}-27,8^{\circ} \mathrm{C}$, kelembaban udara $70 \%$ - 84\%. Suhu rata-rata bulanan minimum $24,6^{\circ} \mathrm{C}$ dan suhu rata-rata bulanan maksimum $34,1^{\circ} \mathrm{C}$ Curah hujan rata-rata tertinggi $537 \mathrm{~mm}$ dengan jumlah hari hujan 23 hari dan September sebesar 0. Adapun kondisi biofisik di areal penanaman cendana di Desa Ponain sebagai berikut : iklim tropis dengan suhu rata-rata $21^{\circ} \mathrm{C}$ $-31^{\circ} \mathrm{C}$, kelembaban udara 64\% (Februari) - 88\% (Juli), penyinaran 50\% (Januari) - 98\% (September) dengan curah hujan $800-1200$ $\mathrm{mm} /$ tahun.

\section{B. Bahan Penelitian}

Bahan yang digunakan dalam penelitian antara lain bibit cendana di persemaian BPK Kupang berumur 7 bulan dan tanaman muda di Desa Ponain umur 4 bulan setelah tanam, kertas tissue, kertas saring, kertas label, alkohol 70\%, formalin 4\%, kloroform, eter, insektisida berbahan aktif karbaril $85 \%$, dan deterjen.

\section{Pengumpulan Data dan Cara Kerja}

Data diperoleh melalui pengamatan bibit di persemaian dan tanaman muda di lapangan terhadap keberadaan hama secara visual. Selain hal tersebut diatas juga dilakukan:

- Pengamatan gejala dan akibat serangan hama kutu sisik, pengamatan gejala dilakukan pada setiap bibit dan tanaman muda yang ada di kedua lokasi.

- Menghitung jumlah bibit di Persemaian BPK Kupang dan di Desa Ponain dan menghitung jumlah tanaman yang terserang hama kutu sisik di kedua lokasi tersebut. Akhirnya diperoleh persentase serangan (PS) yang dihitung dengan rumus sebagai berikut :

Jumlah tanaman yang terserang

PS $=\longrightarrow$ X $100 \%$

Jumlah seluruh tanaman yang diamati

- Pengambilan hama kutu sisik pada bagian daun dan batang cendana yang terserang dengan menggunakan pinset secara perlahanlahan agar kutu sisik tidak rusak, kemudian dimasukkan ke dalam botol koleksi yang telah diisi dengan alkohol $70 \%$ untuk diidentifikasi di laboratorium. Identifikasi dilakukan dengan menggunakan kunci identifikasi Anonim (1991); Kalshoven (1981); Borror et al. (1992); Capinera (2001) dan Pracaya (2007).

- Uji coba pengendalian hama kutu sisik di persemaian BPK Kupang pada bibit umur 7 bulan, dilakukan dengan dua cara yaitu mekanis dan kimia secara bersamaan sebagai berikut : bibit di persemaian yang sudah terserang hama dipisahkan kemudian bagian 
daun dan cabang yang terserang dipotong (potongan daun dan cabang dibakar), setelah dilakukan pemangkasan pada bagian daun dan batang yang terserang kemudian pada bibit tersebut dilakukan penyemprotan dengan insektisida berbahan aktif karbaril $85 \%$ setiap satu minggu sekali dengan dosis 2 gr per liter air. Hal ini dilakukan agar bibit tersebut setelah diberi perlakuan dapat terhindar dari hama kutu sisik. Pengamatan dilakukan seminggu sekali sebelum perlakuan.

- Uji coba pengendalian hama pada tanaman muda umur 4 bulan di lapangan perlakuannya sama dengan di persemaian, hanya insektisida karbaril dicampur dengan deterjen (deterjen bersifat basa untuk membantu menghilangkan sisik/lapisan lilin pada hama sehingga diharapkan insektisida dapat kontak dengan hama). Deterjen juga membantu agar kutu sisik mudah terlepas dari cendana dengan perbandingan $4: 1$, penyemprotan dilakukan satu minggu sekali. Selain perlakuan tersebut untuk tanaman di lapangan dilakukan juga pembersihan lapisan kutu yang masih menempel pada batang utama dengan cara menyikat bagian batang tersebut dengan menggunakan sikat gigi bekas, dan pembersihan tumbuhan bawah secara teratur. Hal ini dilakukan agar bibit tersebut setelah diberi perlakuan dapat terhindar dari hama kutu sisik. Pengamatan dilakukan satu bulan sekali sebelum perlakuan selama 8 bulan.
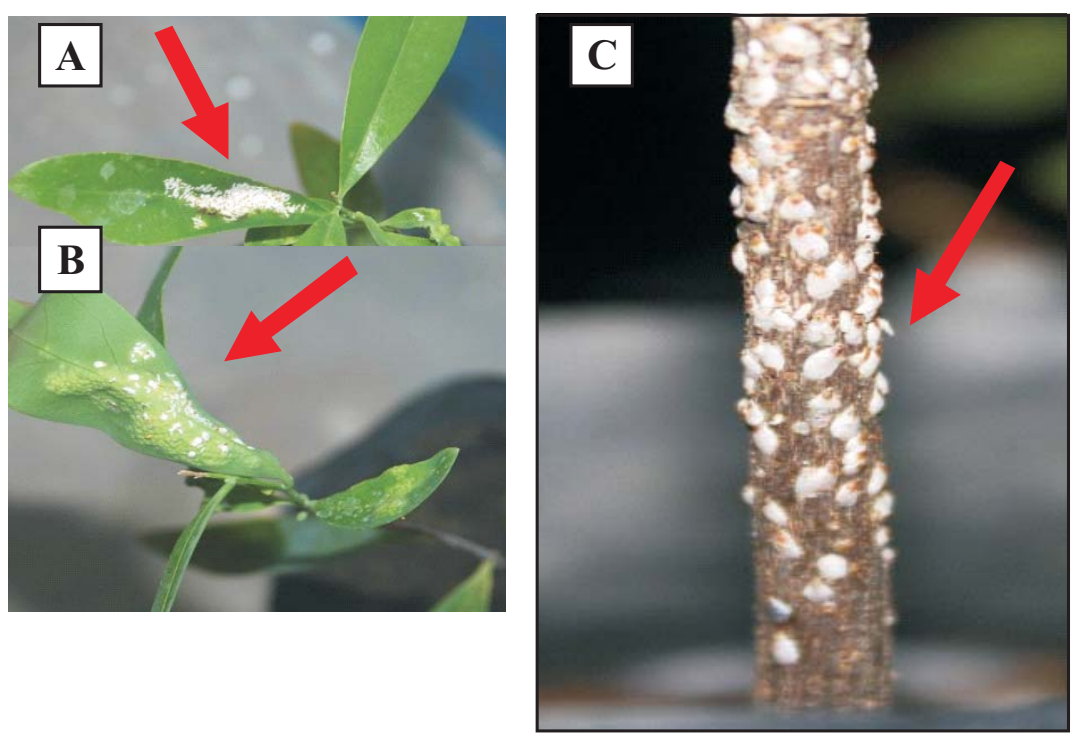

Gambar(Figure) 1. A. Serangan kutu sisik pada permukaan atas daun (Attack of Sandalwood scale insect on top leaf surface), B. Serangan kutu sisik pada permukaan bawah daun (Attack of Sandalwood scale on below leaf surface), C. Serangan kutu sisik pada batang (Attack of Sandalwood scale insect stem).

\section{HASIL DAN PEMBAHASAN}

Kutu sisik menyerang bagian permukaan atas dan permukaan bawah daun cendana, bahkan menyerang ranting dan batangnya. Kutu sisik berkelompok dan seringkali kelompok yang baru menetas tetap berkumpul dekat induknya dan menetap disisa sisiknya, sehingga jumlah populasi menjadi sangat banyak (Gambar 1). Kutu sisik menusuk dan menghisap cairan inang, pada saat menusuk kutu sisik menyuntikan racunnya. Akibat serangan hama kutu sisik maka pada permukaan daun timbul gejala berupa bercak-bercak klorosis yang berwarna hijau muda kekuningan, kemudian bercak menebal dan kemudian membentuk tumor (galls). Pada serangan lanjut, bercak meluas dan berwarna kuning kecoklatan warna daun menjadi semakin kecoklatan (seperti karat) (Gambar 2). Selain itu, daun mengalami perubahan bentuk menjadi menggulung dan mengeriting. Serangan umumnya dimulai pada bagian atas tanaman (pucuk), tanaman cendana yang mengalami serangan lanjut dapat mengalami mati pucuk, defoliasi (pengguguran daun) atau bahkan kematian tanaman.

\section{a. Gejala dan Tanda Kerusakan}



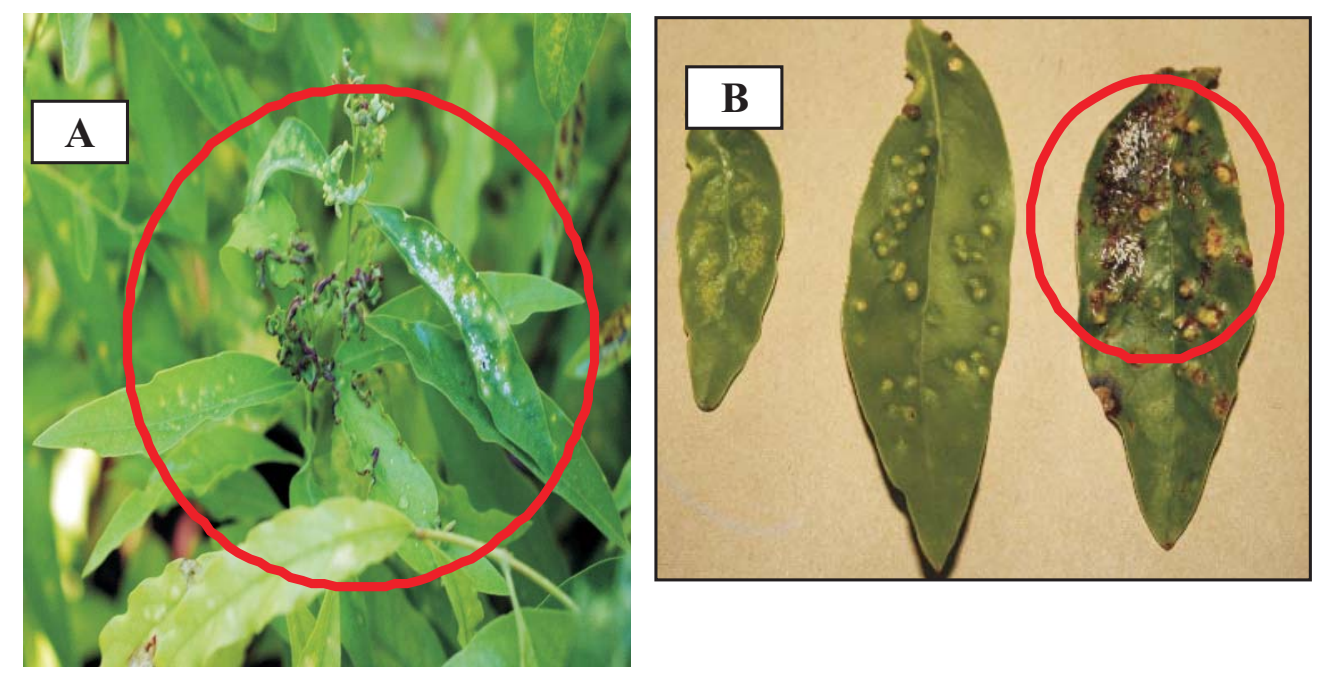

Gambar(Figure) 2. A. Akibat serangan kutu sisik pada pucuk daun cendana (Attack caused sandalwood scale insect on shoot leaf), B. Akibat serangan kutu sisik pada daun cendana (Attack caused sandalwood scale insect on leaf).

\section{b. Persentase Serangan}

Persentase serangan hama adalah proporsi tanaman yang terserang hama dalam suatu populasi tanaman, tanpa menghitung berat atau ringannya tingkat serangan. Hasil pengamatan di persemaian BPK Kupang menunjukkan bahwa pada serangan awal hama kutu sisik persentase serangannya mencapai 20,66\% (Tabel 1). Namun dalam kurun waktu 3 minggu serangan kutu sisik hampir merata pada semua bedeng, artinya persentase serangan meningkat menjadi 100\% (Gambar 3). Sedangkan serangan hama di lapangan persentase serangan mencapai 10,07\% (Tabel 1).

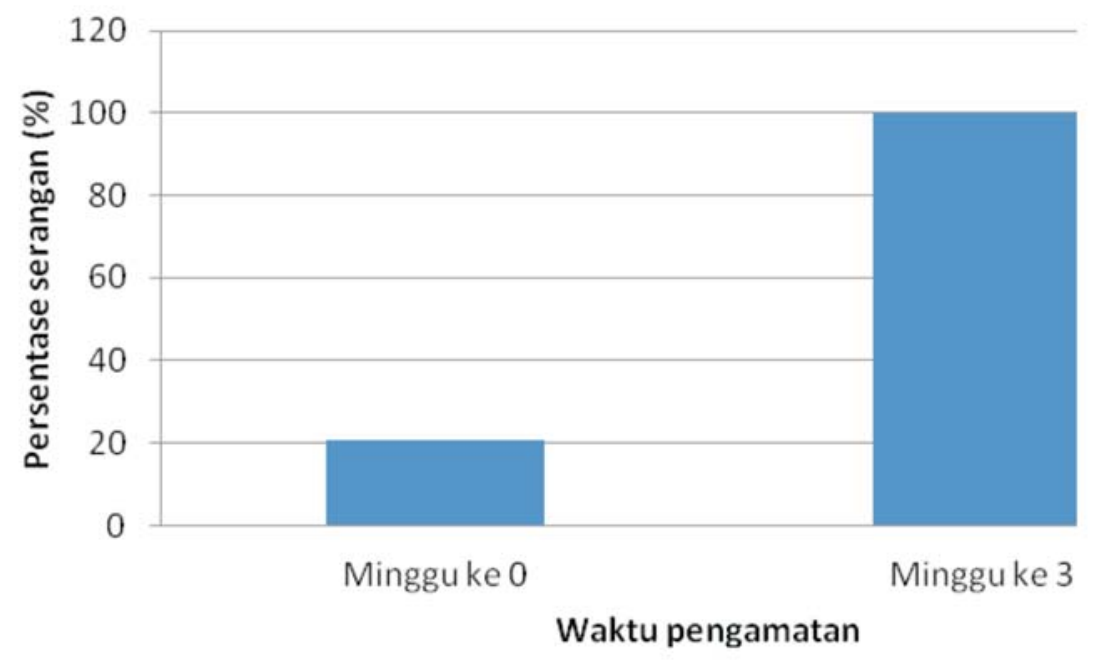

Gambar(Figure) 3. Peningkatan persentase serangan kutu sisik pada bibit di persemaian berdasarkan waktu pengamatan (Sandalwood scale insect attack percentage increasing on seedling based on observation) 
Tabel(Table) 1. Persentase serangan kutu sisik di persemaian BPK Kupang dan tanaman muda di Desa Ponain (Attack percentage of sandalwood scale insect in BPK Kupang nursery and plantation in Ponain village)

\begin{tabular}{l|c|c|c}
\hline \multicolumn{1}{c|}{ Lokasi (Location) } & Jumlah Total (Total) & $\begin{array}{c}\text { Jumlah Terserang } \\
\text { ( } \text { attack) }\end{array}$ & $\begin{array}{c}\text { PS (\%) } \\
\text { (Attack percentage) }\end{array}$ \\
\hline $\begin{array}{l}\text { Persemaian BPK } \\
\text { Kupang (BPK Kupang } \\
\text { nursery) }\end{array}$ & 910 & 188 & 20,66 \\
\hline $\begin{array}{l}\text { Tanaman muda di desa } \\
\text { Ponain (Plantation in } \\
\text { Ponain village) }\end{array}$ & 715 & 72 & 10,07 \\
\hline
\end{tabular}

\section{c. Identifikasi Kutu Sisik}

Hasil identifikasi menunjukkan bahwa hama kutu sisik yang menyerang cendana adalah jenis kutu sisik penghisap cairan tanaman (sap sucking insect) dengan nama ilmiah Chionaspis sp. (Kalshoven, 1981; Borror et al., 1992; Capinera, 2001; Pracaya, 2007; Anonim, 2010). Chionaspis sp. masuk dalam ordo Homoptera, ordo ini merupakan kelompok serangga yang besar dan beragam dan erat kaitannya dengan Hemiptera. Subordo kutu sisik adalah Sternorrhynca, anggota subordo ini umumnya merupakan serangga yang tidak aktif. Banyak dari subordo ini tidak bersayap, beberapa serangga sisik tidak mempunyai tungkai dan sungut, penampilannya tidak seperti serangga (Borror et al., 1992). Kutu sisik cendana masuk ke dalam Superfamili Coccoidea dan famili Diaspididae, kelompok serangga ini betinanya tidak bersayap dan tidak bertungkai serta tidak aktif. Serangga jantan hanya mempunyai sepasang sayap. Serangga betina lebih kecil dan bertubuh lunak bersembunyi di bawah sisik penutup yang terbentuk dari malam yang disekresikan oleh serangga bersama-sama dengan kulit longsongan dari instar awal (Borror et al., 1992). Reproduksi serangga Diaspididae secara biseksual atau partenogenesis, beberapa jenis ovipar dan yang lain melahirkan serangga muda. Telur-telur diletakkan di bawah sisik, instar pertama yang masih muda tersebut merupakan serangga-serangga yang aktif dan dapat berjalan, semakin tua serangga semakin tidak aktif, serta mampu hidup beberapa hari tanpa makan. Serangga merusak tanaman dengan menghisap cairan tumbuhan dan bila populasinya besar tanaman inang akan mati (Borror et al., 1992; Pracaya, 2007).

Serangga bersifat polyfag, antara lain menyerang pinus, kelapa, jeruk, anggrek, kakao, gambir, karet, dan mangga. Bagian yang terserang akan menjadi kuning keemasan, pada serangan berat menjadi abu-abu kemerahan dan akan mati perlahan-lahan. Daun muda yang terserang akan menjadi berkerut-kerut, layu, yang akhirnya daun menjadi kasar dan tanaman mati (Anonim, 1991). Chionaspis sp. diketahui menjadi salah satu hama potensial yang menyerang Santalum spp pada daerah tropis yang kering di Australia Utara (Griffiths et al., 2004).

\section{d. Pengendalian Kutu Sisik Cendana}

Perlakuan insektisida berbahan aktif karbaril $85 \%$ dengan dosis 2 gr per liter air terhadap kutu sisik pada bibit cendana di persemaian belum memberikan hasil yang memuaskan, artinya insektisida tersebut belum dapat mematikan kutu sisik secara tuntas. Tindakan pengendalian berupa pemangkasan cabang atau daun yang terserang hama kutu sisik juga belum efektif, karena trubusan yang tumbuh dari bekas pangkasan terlihat daunnya menggulung dan mengeriting seperti gejala awal serangan hama kutu sisik. Sedangkan hasil pengendalian hama kutu sisik menggunakan insektisida yang sama di lapangan dapat menurunkan persentase serangan sebesar $1,4 \%$ artinya persentase serangan awal 10,07\% menjadi $8,67 \%$ pada enam bulan setelah dilakukannya tindakan pengendalian (Gambar 4). 


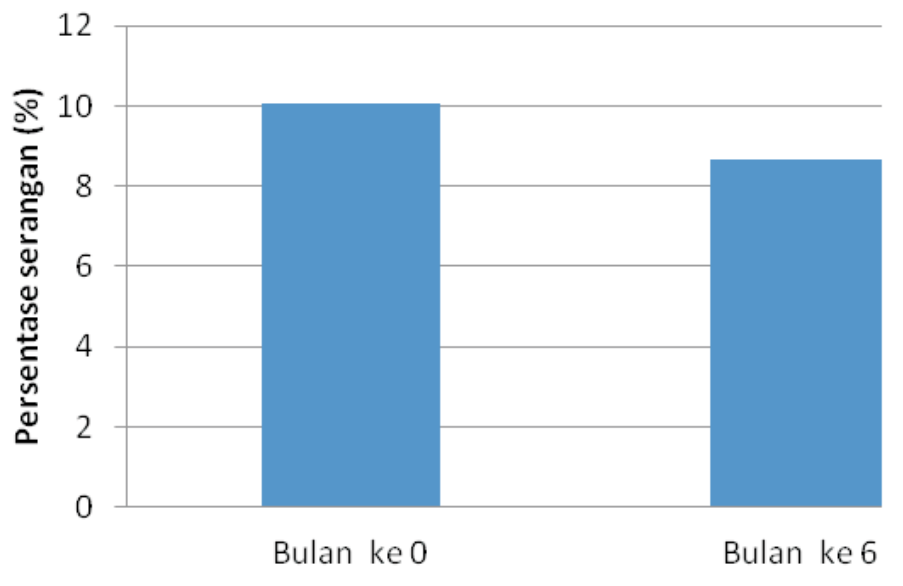

Waktu pengamatan

Gambar(Figure) 4. Penurunan persentase serangan setelah 6 bulan perlakuan (Attack percentage sandalwood scale decreasing after six month treatment)

Pengendalian hama dengan bahan kimia mempunyai kelebihan antara lain mempunyai daya bunuh yang tinggi, penggunaannya mudah dan cepet diketahui (Triharso, 2004). Tetapi apabila penggunaannya tidak rasional maka berpotensi menimbulkan dampak negatif bagi pengguna, konsumen, lingkungan serta dampak sosial ekonomi (Djojosumarto, 2008). Oleh karena itu penggunaan pestisida harus dilakukan secara hati-hati. Tujuan penggunaan pestisida kimia terhadap hama kutu sisik tersebut di atas adalah untuk menurunkan populasi hama tersebut agar keberadaannya tidak menyebabkan kerugian secara ekonomis dan juga dapat menekan kematian bibit. Penggunaan pestisida yang rasional perlu diketahui sifat kimia dan sifat fisik pestisida, biologi dan ekologi hama serta musuh alaminya. Menghindari dampak negatif penggunaan pestisida, maka perlu memperhatikan prinsip-prinsip (Triharso, 2004) :

- Pestisida digunakan bila populasi atau tingkat kerusakan telah mencapai ambang ekonomi.

- Penggunaan pestisida yang berspektrum sempit, mempunyai selektivitas yang tinggi dan konsentrasi dosis yang tepat.

- Pemilihan jenis pestisida yang residunya pendek dan mudah terdekomposisi oleh faktor lingkungan.

- Penggunaan pestisida pada saat hama berada pada titik terlemah.

- Pestisida digunakan hanya apabila pengendalian lain tidak efektif dan efisien lagi.
Untung (2006) mengatakan bahwa insektisida kimia konvensional dapat dibagi menurut sifat dasar senyawa kimianya, yaitu insektisida anorganik (insektisida yang tidak mengandung unsur karbon) dan insektisida organik (insektisida yang mengandung unsur karbon). Sedangkan pembagian insektisida menurut sifat kimia adalah menurut komposisi atau susunan senyawa kimianya. Insektisida organik sintetik dapat dibagi menjadi 5 kelompok berdasarkan susunan kimia bahan aktifnya, yaitu kelompok organoklorin, organofosfat, karbamat, piretroid sintetik dan insect growth regulator.

Hasil pengendalian awal kutu sisik dengan insektisida berbahan aktif karbaril sebenarnya sudah sesuai dengan tujuan dari penggunaan pestisida kimia tersebut yaitu menurunkan populasi kutu sisik. Karbaril termasuk dalam kelompok karbamat. Karbamat merupakan insektisida berspektrum lebar, cara karbamat mematikan serangga melalui penghambatan aktivitas enzim kolinestrase pada sistem saraf. Pestisida dari kelompok karbamat relatif lebih mudah diurai di lingkungan dan tidak terakumulasi oleh jaringan lemak hewani.

Insektisida karbamat yang paling banyak digunakan sampai saat ini adalah karbaril (Gambar 5) (Untung, 2006; Djojosumarto, 2008): 


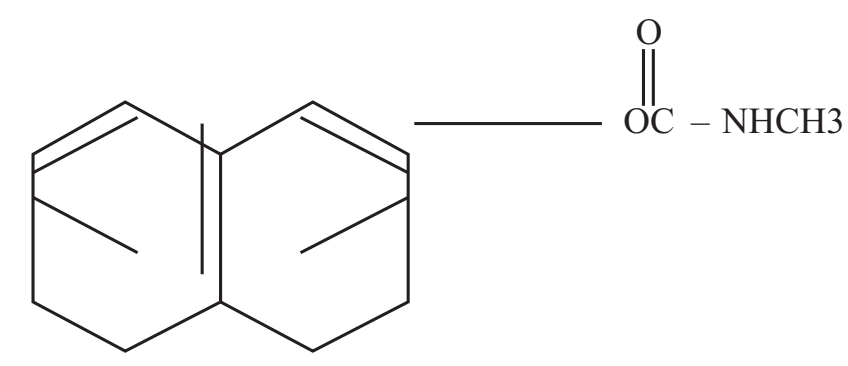

Gambar(Figure) 5. Rumus bangun insektisida dengan bahan aktif karbaril (Chemical structure of insecticide with Karbaril active ingradient)

Djojosumarto (2008) mengatakan bahwa karbaril adalah salah satu insektisida golongan karbamat, yang sangat sukses dipasaran. Insektisida ini digunakan untuk lebih 120 jenis tanaman terutama untuk mengendalikan Lepidoptera, Coleoptera, serangga pengunyah dan penusuk-penghisap.

Kenyataan di lapangan penggunaan insektisida berbahan aktif karbaril tidak dapat mematikan kutu sisik secara tuntas, sedangkan hasil pengendalian hama kutu sisik menggunakan insektisida yang sama di lapangan dapat menurunkan persentase serangan sebesar $1,4 \%$. Hal ini ada beberapa kemungkinan yang terjadi dalam penggunaan karbaril untuk pengendalian kutu sisik, yaitu seperti apa yang dikatakan oleh Djojosumarto (2008) bahwa kegagalan pengendalian organisme pengganggu tanaman (OPT) dengan pestisida bisa disebabkan oleh salah satu atau beberapa faktor antara lain :

- Pestisida yang digunakan tidak cocok untuk OPT yang sedang dihadapi.

- OPT tidak peka lagi terhadap pestisida bersangkutan (resisten).

- Pestisida diaplikasikan dengan teknik (waktu, takaran dan cara) yang keliru.

Berkembangnya suatu populasi serangga dari yang semula peka menjadi kurang peka dan akhirnya kebal (resisten) terhadap pestisida tertentu merupakan proses seleksi alam. Dalam hal ini individu-individu yang paling kuat dan paling bisa menyesuaikan diri (dalam hal ini tahan terhadap insektisida) akan tetap bertahan hidup, sedangkan individu yang tidak bertahan hidup akan punah.

\section{KESIMPULAN}

Hama kutu sisik yang menyerang bibit cendana dan tanaman muda di Kupang, Nusa Tenggara Timur adalah Chionaspis sp. masuk dalam famili Diaspididae. Pengendalian dengan insektisida berbahan aktif karbaril 85\% di tingkat semai belum menunjukkan hasil yang signifikan, sedangkan di tingkat lapangan dapat menurunkan persentase serangan sebesar 1,4\%, persentase serangan awal sebelum perlakuan $10,07 \%$ setelah perlakuan menjadi $8,67 \%$.

\section{DAFTAR PUSTAKA}

Anonim. 1991. Kunci Determinasi Serangga. Program Nasional Pelatihan dan Pengembangan Pengendalian Hama Terpadu. Kanisius. Jogjakarta.

Anonim. 2010. Mengharumkan Kembali Cendana di NTT. Siaran pers No. S84/ PIK-1/2009. Http://www.dephut.go.id/ index.php?q=id/node/5154. Diakses 10 Februari 2010.

Borror, D J., C.A. Triplehorn and NF. Johnson. 1992. An Introduction to the Study of Insect (Pengenalan Pelajaran Serangga Penerjemah drh. Soetiyono Partosoedjono, M.Sc. dan Prof. Dr. Mukayat Djarubito Brotowidjoyo, M.Sc.). Gadjah Mada University Press. Jogjakarta.

Capinera, J.L. 2001. Handbook of Vegetable Pests. Academic Press. USA.

Djojosumarto, P. 2008. Pestisida dan Aplikasinya. PT. Agromedia Pustaka. Jakarta.

Griffiths, M., R. Wylie, S. Lawson, G. Pegg, and J. McDonald. 2004. Known or Potential Treats from Pest and Disease to Prospective Tree Species for High Value Timber Plantings in Nothern Australia. Mareeba. Australia. 
Kalshoven, L.G.E. 1981. Pest of Crops In Indonesia. P.T. Ichtiar Baru-Van Hoeve. Jakarta.

Pracaya. 2007. Hama dan Penyakit Tanaman (edisi revisi). Penebar Swadaya. Jakarta.

Surata, I.K. 2006. Teknik Budidaya Cendana. Balai Penelitian dan Pengembangan Kehutanan Bali dan Nusa Tenggara. Kupang-Indonesia.
Triharso. 2004. Dasar-dasar Perlindungan Tanaman. Gadjahmada University Press. Yogyakarta.

Untung, K. 2006. Pengantar Pengelolaan Hama Terpadu (edisi kedua). Gadjah Mada University Press. Yogyakarta. 